\title{
Infrared Radiation Therapy
}

National Cancer Institute

\section{Source}

National Cancer Institute. Infrared Radiation Therapy. NCI Thesaurus. Code C71590.

The use of infrared radiation to heat a specific tissue for the purpose of treating an injury or illness. 